\title{
Depositional setting and early diagenesis of the dinosaur eggshell-bearing Aren Fm at Bastus, Late Campanian, south-central Pyrenees
}

\author{
Margarita Díaz-Molina ${ }^{\mathrm{a}, *}$, Otto Kälin ${ }^{\mathrm{b}}$, M. Isabel Benito ${ }^{\mathrm{a}}$, \\ Nieves Lopez-Martinez ${ }^{\mathrm{b}}$, Enric Vicens ${ }^{\mathrm{c}}$ \\ ${ }^{a}$ Departamento de Estratigrafía, Facultad de Ciencias Geológicas e Instituto de Geología Económica (CSIC), \\ Universidad Complutense de Madrid, 28040 Madrid, Spain \\ ${ }^{\mathrm{b}}$ Departamento de Paleontología, Facultad de Ciencias Geológicas e Instituto de Geología Económica (CSIC), \\ Universidad Complutense de Madrid, 28040 Madrid, Spain \\ ${ }^{c}$ Department de Geología, Facultat de Ciènces, Universitat Autonoma de Barcelona, 08193, Bellaterra, Barcelona, Spain
}

Received 9 June 2006; received in revised form 26 January 2007; accepted 2 February 2007

\begin{abstract}
The Late Cretaceous Aren Fm exposed north of Bastus in the Tremp Basin (south-central Pyrenees) preserves an excellent record of dinosaur eggs laid in a marine littoral setting. Different from other cases reported in literature, at the Bastus site the preferential nesting ground was original beach sand. The coastal deposits of Aren Fm can be grouped into four facies assemblages, representing respectively shoreface, beachface, beach ridge plain and backbarrier lagoon environments. Shoreface deposits include fine- to coarsegrained hybrid arenites and subordinate quartz-dominated conglomerates with ripple structures of wave and wave-current origin. Beachface deposits are mainly storm beach conglomerates, but parallel-laminated foreshore arenites locally occur. Backbarrier lagoon deposits comprise of washover sandy conglomerates that grade laterally into sandy lime mudstones, biomicrites and marls.

Beach ridge sediment, wherein the bulk of dinosaur eggs and eggshell debris occurs, predominantly is a reddish hybrid arenite that has undergone a complex early diagenetic evolution, including marine and meteoric cementation followed by soil development. The reddish arenites overlie wave-dominated shoreface deposits and in places pass laterally into lagoonal deposits. They originally formed shore ridges, that became stabilized during progradational episodes by pedogenesis (beach ridge, sensu [Otvos, E.G., 2000. Beach ridges - definitions and significance. Geomorphology 32, 83-108.]), which also affected the dinosaur eggs. The eggshell-bearing beach ridge arenites are typically preserved at the top of parasequences forming the systems tracts of a third-order sequence. Thick packages of this facies resulted from aggradation of barrier/beach ridge deposits, whose preservation below surfaces of transgressive erosion was favoured by incipient lithification.
\end{abstract}

Keywords: Paleoenvironments; Beach ridges; Dinosaur eggs; Diagenesis; Cretaceous

\section{Introduction}

In 1995, Sanz et al. presented evidence for dinosaur

* Corresponding author.

E-mail address: margot@geo.ucm.es (M. Díaz-Molina). nesting in marine beach sands from the Late Campanian Aren Sandstone Fm exposed north of the locality of Bastus 
(Tremp Basin, south-central Pyrenees; Fig. 1). Such an interpretation was based on sedimentological and petrological arguments, suggesting that nesting occurred in shoreline sands, after beach abandonment and before consolidation and pedogenesis. The study centred on a 2 m-thick package of reddish arenite containing wellpreserved clutches of dinosaur eggs and very abundant eggshell debris (cf., Fig. 2 for location). In fact, for this egg
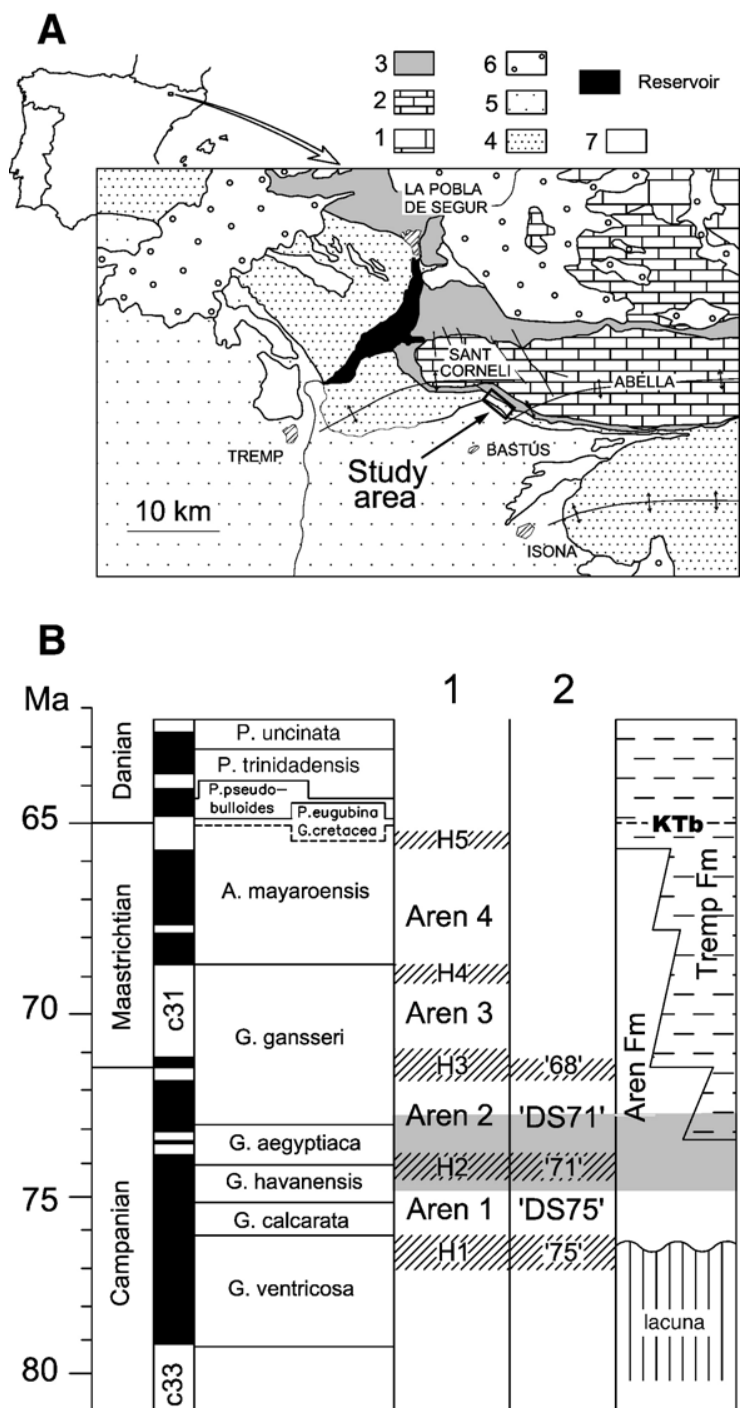

Fig. 1. (A) Location map of the exposure studied (geology after Losantos et al., 2002, modified): (1) Barremian-Aptian; (2) AptianSantonian; (3) Santonian-Campanian; (4) Campanian-Maastrichtian; (5) Maastrichtian-lower Eocene; (6) upper Eocene-Oligocene; (7) Quaternary. (B) Synthetic stratigraphic framework; (1) depositional sequences and sequence boundaries (approximate position) after Ardèvol et al. (2000); (2) correlative depositional sequences ('DS') of Déramond et al. (1993). Grey box marks the stratigraphic interval considered in this study. site Sanz et al. (1995) estimated that a rock volume of $12,000 \mathrm{~m}^{3}$ contains the remains of some 300,000 eggs and Sander et al. (1998) inferred an occupation time in the order of 10,000 years for the same site. The abundance of clutches and eggshell debris at this locality was considered to indicate nesting site fidelity.

Subsequent work in the area concerned with the Aren Fm revealed that this occurrence is not unique, but that eggshell-bearing red arenites are frequently preserved at the top of parasequences, and that their spatial distribution was presumably controlled by coastal evolution and sealevel changes. The red arenites do not preserve diagnostic primary sedimentary structures, and depositional texture and composition were strongly altered during nesting and early diagenesis. Nevertheless, sedimentological and petrological analysis, along with the use of geomorphological concepts, allowed us to interpret these deposits as beach ridges sensu (Otvos, 2000). The designation 'beach ridge', as defined by this author, applies to relict eolian and wave-built shore ridges isolated from the active beach zone by shoreline progradation, and becoming gradually stabilized by vegetation.

In the studied exposure, sandbodies identified as beach ridges are similar in composition to the rocks representing the shoreface, as is in fact observed in recent beach ridges (e.g., Taylor and Stone, 1996). Beach ridge facies occur associated with other types of coastal deposits, the interpretation of some of which varies between authors, ranging from shelf-nearshore (e.g., Nagtegaal et al., 1983; Puigdefábregas and Souquet, 1986; Díaz-Molina, 1987; Simó, 1989; Arbués and Berástegui, 1996) to fluviodeltaic (Ardèvol et al., 2000). The present contribution aims at providing a more detailed sedimentological and petrological description of these shoreline facies and their depositional architecture. Moreover, the facies hosting the dinosaur clutches at Bastus, and the inferred environmental setting, markedly differ from other recently published cases, where concentrations of clutches and eggshell debris are reported to occur preferentially in muddy alluvial/ fluvial or lake shore/perilagoonal deposits with associated paleosols (e.g., Tandon et al., 1995; Dingus et al., 2000; Cojan et al., 2003; Escuer et al., 2003; Paik et al., 2004; Van Itterbeeck et al., 2004), and exceptionally in muddy tidal flat sediment (Lopez-Martinez et al., 2000).

\section{Geological setting}

The exposure studied, covers an area of approximately $0.5 \times 0.2 \mathrm{~km}$, located in the footwall (TrempSellent syncline) to the Sant Corneli fault propagation anticline at the leading edge of the Boixols thrust sheet (Fig. 1A). The stratigraphic succession considered 


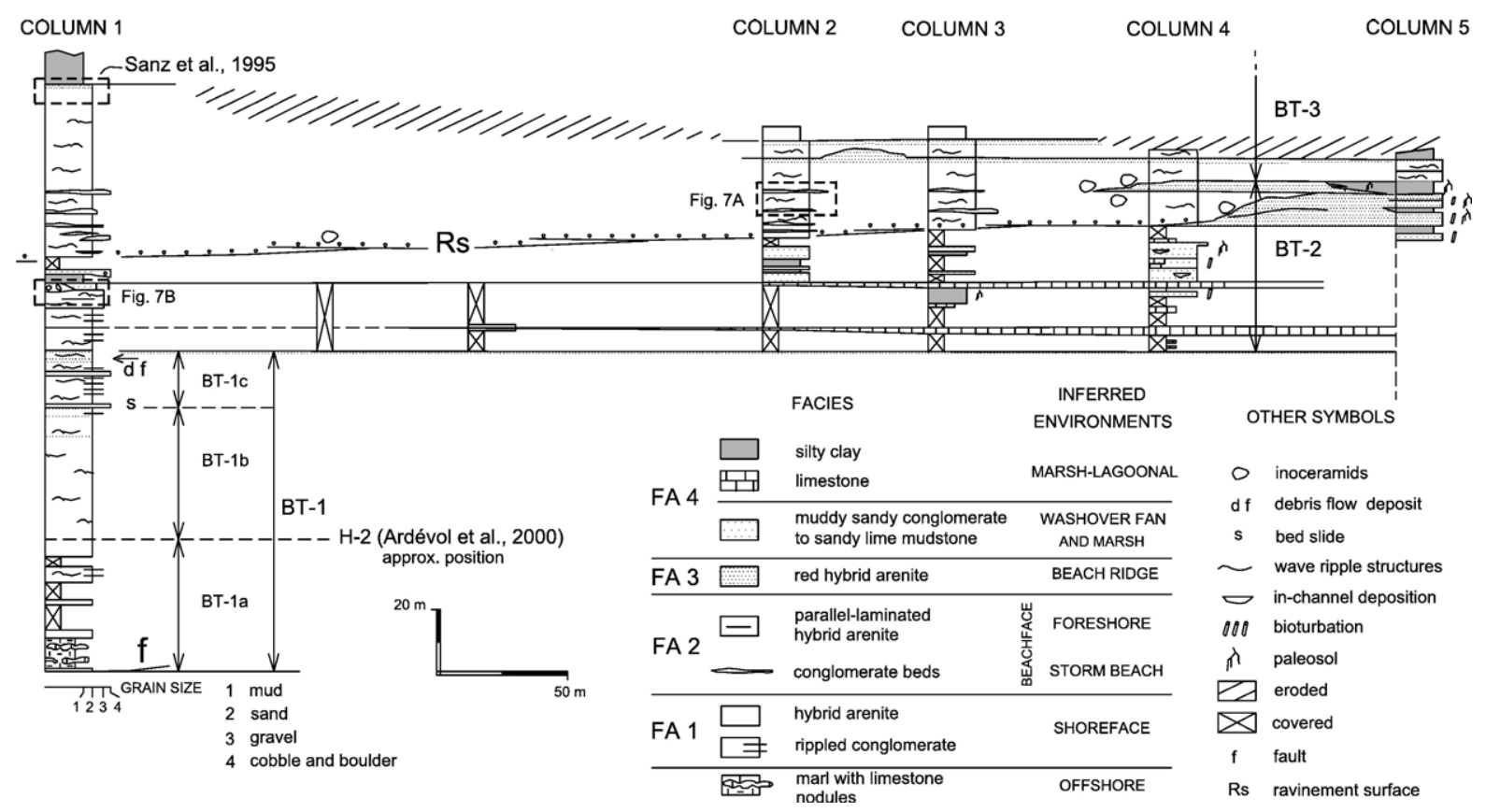

Fig. 2. Upper Campanian stratigraphic record near Bastus showing interpreted sedimentary facies. H-2 marks approximate position of boundary between the Aren-1 and Aren-2 third-order sequences according to Ardèvol et al. (2000). Location of Fig. 7A and B in columns 2 and 1 respectively.

(Fig. 2) includes part of the Aren Fm and the lower portion of the Tremp Fm (Mey et al., 1968). The Aren Fm consists of shallow-marine clastic deposits and exhibits progressive unconformities and facies variations, related to the contemporaneous growth of the Sant Corneli inversion anticline (Garrido Mejias, 1973; Simó, 1986; Puigdefábregas and Souquet, 1986; Déramond et al., 1993; Bond and McClay, 1995; Arbués and Berástegui, 1996), which could have emerged as an island/peninsula during latest Cretaceous time (Nagtegaal et al., 1983). On a regional scale, the Aren Fm shows a general NW prograding trend, becoming gradually replaced landwards (E and $\mathrm{S}$ ) by estuarine, lagoonal and continental deposits of the lower part of the Tremp Fm (e.g., Nagtegaal et al., 1983; Díaz-Molina, 1987; Eichenseer, 1988; Ardèvol et al., 2000).

The Aren sandstones are 'mixed assemblages of autochthonous (i.e., intrabasinal) and allochthonous (i.e., extrabasinal) components' (Nagtegaal et al., 1983). Among the former, worn fossil fragments (bivalves, echinoderms, bryozoans, larger foraminifera and coralline algae) prevail. Extrabasinal components are constituted predominantly by different types of quartz grains, some K-feldspar, chert, quartzite and mica.

The depositional architecture of the Upper Cretaceous strata in the Tremp area constitutes the subject of several papers (Simó, 1989; Déramond et al., 1993;
Sgavetti, 1994; Ardèvol et al., 2000). However, interpretations offered differ widely with regard to the number and/or order of the depositional sequences distinguished, and the type of mutual relationships.

Ardèvol et al. (2000) proposed a division of the Aren Fm and its correlative continental and basinal deposits into four third-order depositional sequences, referred to as Aren-1 to Aren-4, delimited by five sequence boundaries labelled H-1 to H-5 (cf., Fig. 1B). According to these authors, each of these third-order sequences spans about 2 to $3 \mathrm{Ma}$, consists of a 'siliciclastic-carbonate package' and represents a type-1 sequence sensu (Van Wagoner et al., 1988). The exposure described here comprises the topmost portion of the Aren- 1 and part of the Aren-2 third-order sequences of Ardèvol et al. (2000), that seem to correspond to part of what Déramond et al. (1993) called their depositional sequences 'DS 75' and 'DS 71' respectively.

Sequence boundary H-2 (between Aren-1 and Aren-2; Fig. 2) overlies the G. calcarata biozone (top $\sim 75 \mathrm{Ma}$ ), and precedes the $G$. gansseri biozone (bottom $\sim 72-$ 73 Ma, Lopez-Martinez et al., 2001; time scale: Hardenbol et al., 1998). The boundary H-3 at the top of the Aren-2 sequence is located in the middle of the G. gansseri biozone ( 71 Ma, Hardenbol et al., 1998; Gradstein et al., 2004). Accordingly, the section described here would probably represent a time period of less than $2 \mathrm{Ma}$. 


\section{Depositional facies and diagenesis}

In the upper Campanian sedimentary record at Bastus, four major facies assemblages (FA) can be distinguished which represent shoreface, beachface, beach ridge plain and backbarrier lagoon environments (Fig. 2 and Table 1). In the western portion of the studied exposure the bulk of the stratigraphic succession, $180 \mathrm{~m}$ thick, is formed by wave-rippled shoreface sediments organized in meter-thick packages (FA 1), which overlie $35 \mathrm{~m}$ of alternating offshore and shoreface deposits (column 1, Fig. 2). Eastwards, backbarrier and lagoonal deposits (FA 4) interfinger with open marine deposits (FA 1-3), and progressively increase in thickness (columns 2 through 5, Fig. 2). These facies constitute three major units, termed BT-1, BT-2 and BT-3.

Petrographic analysis centred on aspects of early diagenesis that affected the various depositional facies

Table 1

Summary of depositional facies distinguished and their environmental interpretation

\begin{tabular}{|c|c|c|c|}
\hline Facies association & Facies/Lithology & Characteristic components & Environment \\
\hline \multirow[t]{2}{*}{ FA 1} & $\begin{array}{l}\text { Dominant: fine- } \\
\text { to coarse-grained } \\
\text { hybrid arenite with } \\
\text { wave or wave- } \\
\text { current ripples }\end{array}$ & $\begin{array}{l}\text { Carbonate skeletal grains: benthic } \\
\text { foraminifera, bryozoans, } \\
\text { echinoderms, coralline algae, } \\
\text { bivalves and scarce gastropods; } \\
\text { iron-stained arenite intraclasts and } \\
\text { inoceramid shells/shell fragments }\end{array}$ & Shoreface \\
\hline & $\begin{array}{l}\text { Subordinate: granule } \\
\text { conglomerates with } \\
\text { 'coarse grained ripple' } \\
\text { structures (Leckie, 1988) }\end{array}$ & Quartz-dominated & Shoreface \\
\hline \multirow[t]{3}{*}{$\begin{array}{l}\text { FA } 2 \\
\quad \text { (beachface) }\end{array}$} & $\begin{array}{l}\text { Dominant: conglomerate beds with } \\
\text { three facies: }\end{array}$ & & $\begin{array}{l}\text { Storm gravel } \\
\text { beach }\end{array}$ \\
\hline & $\begin{array}{l}\text { Boulder and cobble framework filled } \\
\text { with pebbles, sand and granule: } \\
\text { 'initial ridge' (Bluck, 1967) } \\
\text { Cobble and pebble framework: 'infill zone' } \\
\text { (Bluck, 1967) } \\
\text { Cobbles and pebbles 'floating' in } \\
\text { finer grained matrix: 'outer frame } \\
\text { zone' (Bluck, 1967) }\end{array}$ & $\begin{array}{l}\text { Boulders of hybrid arenite (Aren } \\
\text { Fm); cobbles and pebbles of hybrid } \\
\text { arenite (Aren Fm), shelf limestones, } \\
\text { coral and rudists fragments (from } \\
\text { older formations), lagoonal } \\
\text { limestone clasts and inoceramid } \\
\text { shells; granules are predominantly } \\
\text { quartz and the sand fraction is of } \\
\text { mixed (hybrid) siliciclastic and } \\
\text { carbonate composition }\end{array}$ & (Bluck, 1967) \\
\hline & $\begin{array}{l}\text { Subordinate: parallel-laminated } \\
\text { hybrid arenite to granule } \\
\text { conglomerate }\end{array}$ & & Foreshore \\
\hline \multirow[t]{2}{*}{ FA 3} & $\begin{array}{l}\text { Dominant: red (Fe)-stained, nodular } \\
\text { and breccified (pedogenically } \\
\text { altered) fine- to medium-grained } \\
\text { hybrid arenite }\end{array}$ & $\begin{array}{l}\text { Carbonate skeletal grains (partially } \\
\text { leached): similar to those of } \\
\text { shoreface deposits; dinosaur eggs } \\
\text { and eggshell fragments, as well as } \\
\text { fully preserved egg clutches }\end{array}$ & $\begin{array}{l}\text { Beach ridge } \\
(\text { Otvos, 2000) }\end{array}$ \\
\hline & $\begin{array}{l}\text { Subordinate: conglomerates of } \\
\text { hybrid arenite clasts }\end{array}$ & & \\
\hline \multirow[t]{4}{*}{$\begin{array}{l}\text { FA } 4 \\
\text { (backbarrier lagoon) }\end{array}$} & $\begin{array}{l}\text { Sandy conglomerates with faint } \\
\text { lamination grading into massive and } \\
\text { bioturbated sandy lime mudstones; } \\
\text { in cases scour-based and with lag } \\
\text { deposits }\end{array}$ & $\begin{array}{l}\text { Carbonate skeletal grains: fragments of red algae, } \\
\text { molluscs, benthonic foraminifera dinosaur bones/bone } \\
\text { fragments and eggshell debris }\end{array}$ & Washover apron \\
\hline & $\begin{array}{l}\text { Clast-supported cobble and pebble } \\
\text { conglomerate filling small channels }\end{array}$ & $\begin{array}{l}\text { Composition similar to that of gravel } \\
\text { beaches }\end{array}$ & $\begin{array}{l}\text { Throat plugs or } \\
\text { channels (behind } \\
\text { barriers) }\end{array}$ \\
\hline & $\begin{array}{l}\text { Massive silty clays with traces of } \\
\text { plant roots and colour mottling; } \\
\text { occasional carbonate concretions }\end{array}$ & & $\begin{array}{l}\text { Shallow lagoon, } \\
\text { marsh }\end{array}$ \\
\hline & Biomicrites and marls & $\begin{array}{l}\text { Carbonate skeletal grains: } \\
\text { ostracods, charophytes and } \\
\text { gastropods }\end{array}$ & Lagoon \\
\hline
\end{tabular}




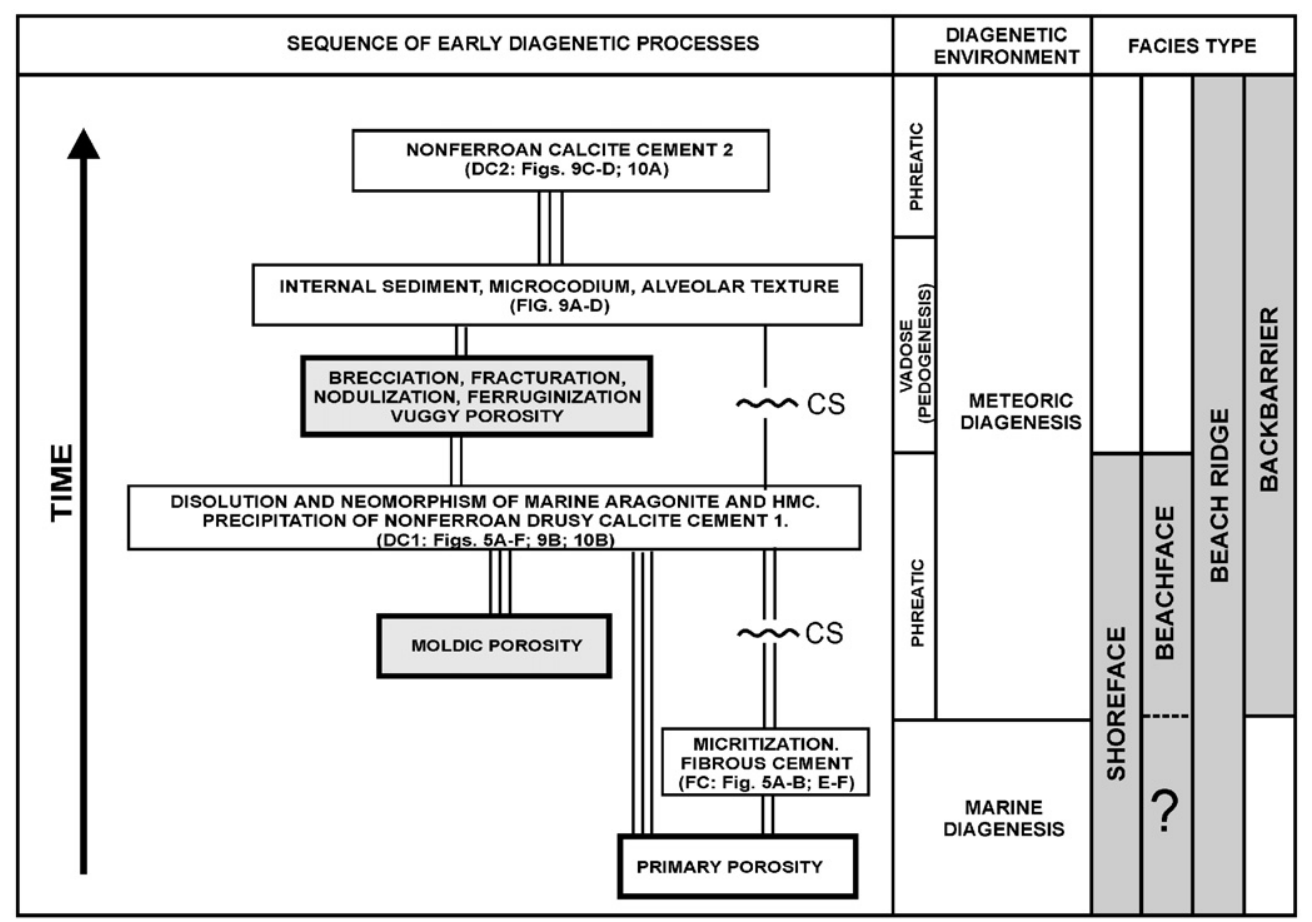

Fig. 3. Relative timing of early diagenetic events/processes recorded in the different sedimentary facies of the Aren Fm (FA 1-4, marked by grey bars). Vertical lines connect successive events, as deduced from cross-cutting/textural relationships; number of lines indicates relative frequency: very common $(\|||)$, common $(\|)$, and uncommon $(\mid)$. The diagram also shows the interpreted succession of diagenetic environments. CS: corrosion surface.

in the near-surface realm. 85 Thin sections were studied by conventional petrographic and cathodoluminescence (CL) microscopy, in order to reveal the pattern of diagenesis and interpret the processes involved, establish their relative timing and the diagenetic environments where they operated. CL petrograhy was carried out using a Technosyn Mk 4 cold cathode device. After examination under $\mathrm{CL}$, selected thin sections were stained with Alizarin Red S and potassium ferricyanide (Dickson, 1966), in order to distinguish between ferroan and nonferroan phases in calcite cement. The results obtained are summarized in Fig. 3.

\subsection{Shoreface deposits (FA 1)}

Throughout the lowermost portion of the studied succession (subunit BT-1a, Fig. 2), shoreface deposits alternate with offshore marls. The former consist of wave-rippled, fine- to medium-grained arenite with the framework dominated by carbonate skeletal grains (benthic foraminifera, briozoans, equinoderms, coralline algae, bivalves and gastropods).

Shoreface deposits in subunits BT- $1 \mathrm{~b}$ and $-1 \mathrm{c}$ include fine- to coarse-grained hybrid arenites, similar in composition to those of subunit BT-1a, except for a higher content in siliciclastic grains, a minor proportion of bryozoans and the occurrence of dinosaur eggshell fragments, as well as of rounded, iron-stained hybrid arenite intraclasts (Fig. 4A). Interbedded with these arenites conglomerate layers, up to a few decimeters thick, occur, composed exclusively of granule-size or somewhat coarser (up to $6 \mathrm{~mm}$ ) quartz clasts and with 'coarse-grained ripple' structures (Leckie, 1988). These commonly record unidirectional flow, although in some cases bidirectional cross-bedding is observed. Some beds are faintly cross-bedded or structureless (Fig. 4B). Similar structureless deposits have been reported by Leckie (1988) as a common type of facies associated with coarse-grained ripples, and the apparent lack of lamination interpreted as an effect of the poorly sorted nature of the sediment. Coarse-grained ripples occur in modern nearshore deposits in water depths ranging from 3 to $160 \mathrm{~m}$ (Clifton, 1973; Leckie, 1988), or below the swash zone (Clifton et al., 1971; Hart and Plint, 1989).

Very early diagenetic processes that affected these deposits include partial micritization of carbonate grains and a first phase of marine cementation in primary intergranular and intraskeletal pores. Micrite envelopes, up to $10 \mu \mathrm{m}$ thick, exhibit brownish dull luminescence and they are generally the only feature recording the 

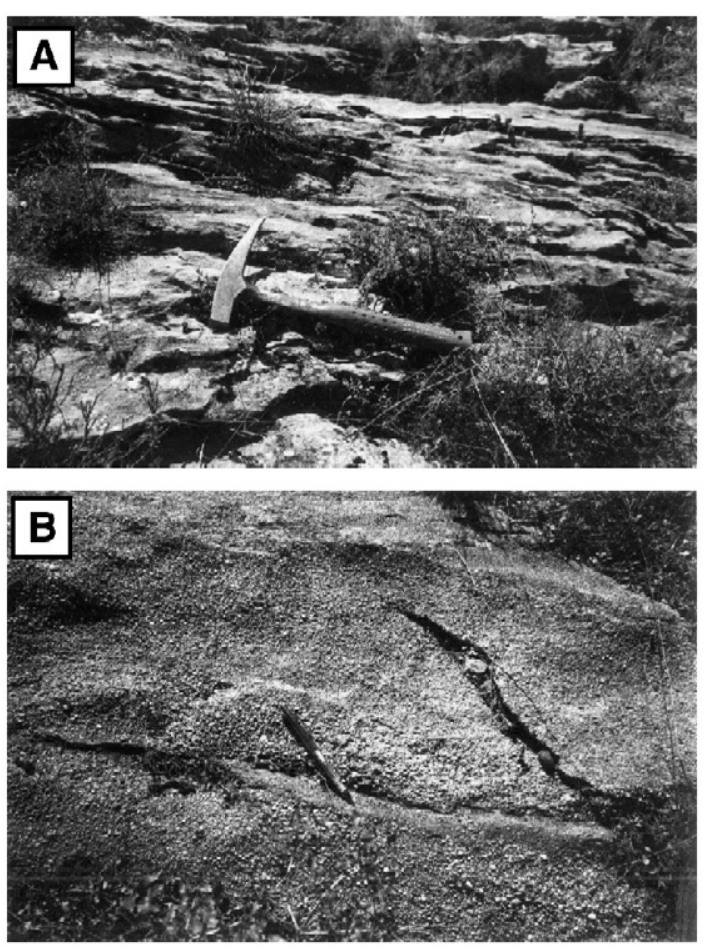

Fig. 4. (A) Coarse-grained hybrid arenite with typical wave ripple structures. (B) Faintly cross-bedded granule conglomerate.

original shape of mineralogically metastable skeletal grains (aragonite/high magnesium calcite) that were dissolved during subsequent stages of diagenesis. The first generation of cement is represented by rims of isopachous nonferroan calcite, up to $40 \mu \mathrm{m}$ thick, that show dark dull or "patchy" (dark-bright) luminescence (Fig. 5A, B). This cement, not observed in all samples, preserves a relic fibrous texture typical of neomorphosed marine cements (e.g., Tucker and Wright, 1990). The presence of relics of such early marine cement lining both intergranular and intragranular pores indicates that the skeletal components have not been reworked from older formations.

Relic fibrous cement is overlain by a mosaic of nonferroan to slightly ferroan drusy calcite cement. Where relic fibrous cement is absent, or not preserved (dissolved), the drusy spar is the only cement occurring within primary porosity. Moldic porosity left after wholesale dissolution of metastable skeletal components, is also filled by drusy nonferroan calcite cement (Fig. 5A). Drusy cement, both in primary and secondary moldic pores is mainly nonluminescent, or shows oscillatory zoning (non/ bright/dull: NL-BL-DL; Fig. 5B).

The petrographic characteristics of nonferroan to slightly ferroan drusy cement indicate that it precipitated in a near-surface meteoric phreatic environment (e.g.,
James and Choquette, 1990). Therefore, after deposition and incipient cementation in a marine setting, the shoreface deposits were exposed subaerially and flushed by meteoric waters. In this diagenetic environment, marine aragonitic and high magnesium calcite components were dissolved (generating moldic porosity) and/ or neomorphosed. Subsequently, drusy nonferroan to slightly ferroan meteoric calcite cement precipitated in both the residual primary and the secondary (moldic) porosity.

\subsection{Beachface (FA 2)}

Beachface deposits are represented by storm beach conglomerates and subordinate foreshore arenites to granule conglomerate. Foreshore deposits consist of beds, up to a meter thick, with characteristic low-angle parallel lamination which may present low-angle truncation planes separating individual sets (e.g., in subunit BT-1c and unit 2, column 1, Fig. 2). Parallel lamination develops as a result of wave swash on the beachface, whereas the truncation planes represent adjustment of the beach to changes in wave regime or sediment supply (McCubbin, 1982).

Conglomerate beds form irregular and laterally extensive deposits, and are calcite cemented. Their lower contacts are sharp and in some cases erosive over the underlying shoreface sediments (FA 1), and may show load structures. The upper boundaries tend to be irregular and in some cases preserve some convexupward relief. Size and shape sorting of gravel occur during both the build-up and the breakdown phases of gravelly beaches (Bluck, 1967), allowing the distinction of three (Postma and Nemec, 1990) or four (Bluck, 1967; Williams and Caldwell, 1988) shore parallel zones. Two dominant conglomeratic facies have been distinguished in the studied exposure, which are comparable with the 'initial ridge of gravels' and the 'infill zone' facies of the Sker type beach described by Bluck (1967). Less frequently, an additional type of facies is found, which is thought to correspond to the 'outer frame zone' described by Bluck (1967).

The deposits attributed to Bluck's 'initial ridge of gravels' facies are up to $80 \mathrm{~cm}$ thick and show a cobble and boulder framework filled with pebbles, sand and granules. Occasionally disc-shaped outsize clasts are observed at the top of beds (Fig. 6A). Boulders are of hybrid arenite composition (Aren Fm), and some of them contain dinosaur eggshell fragments. In the upper portion of the conglomerate beds, infiltration of granule and small pebble gravel into open interstices between coarser clasts is frequently observed (Figs. 6B and 7A). 
Conglomerates of the 'infill zone' facies are up to $50 \mathrm{~cm}$ thick and show the same composition. The framework is formed by cobbles and pebbles and the interstices filled with finer grained material. These sediments formed by the breakdown of a previous framework of cobbles, later infilled by pebbles, granules
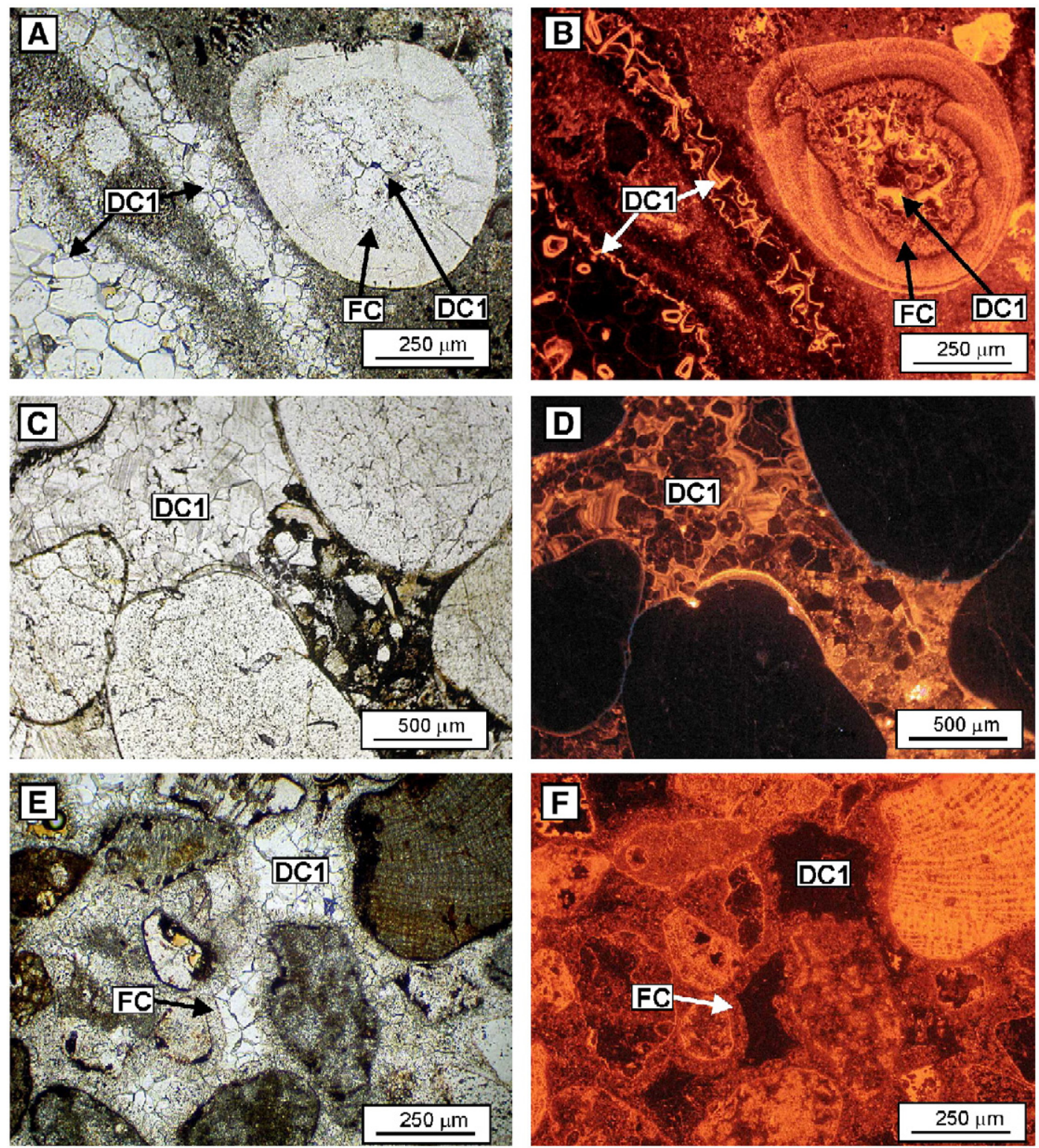

Fig. 5. Transmitted light (left) and CL photomicrographs (right) showing early diagenetic phases of shoreface (A, B), beachface (C, D) and beach ridge (E, F) deposits: (A) calcite cements filling primary and secondary porosity. Primary intraskeletal porosity is filled by an isopachous rim of relic fibrous calcite cement (FC) followed by a drusy mosaic of nonferroan calcite (DC1) that occludes the pore. Secondary mouldic porosity (left) is filled exclusively by a drusy mosaic of nonferroan calcite cement (DC1). (B) Same photograph under CL. Relic fibrous cement (FC) shows dull orange luminescence (DL) and the drusy calcite mosaic (DC1), both in intraskeletal and mouldic pores, oscillatory zoning (nonluminescent-bright yellowish, NL-BL). Whereas NL nonferroan calcite cement typically precipitates under oxidizing conditions (e.g., Scholle and Ulmer-Scholle, 2003), BL is caused by relatively high $\mathrm{Mn} / \mathrm{Fe}$ ratios and DL occurs when $\mathrm{Mn} / \mathrm{Fe}$ ratios decrease. BL and DL areas precipitate under sub-oxic to reducing conditions (e.g., Meyers, 1991). (C) Intergranular porosity partially filled by geopetal hybrid arenite. Porosity is occluded by a drusy mosaic of nonferroan calcite cement (DC1). (D) Same photograph under CL. Showing oscillatory zoning NL-DL in drusy calcite (DC1). (E) Hybrid arenite with framework grains rimmed by relic fibrous calcite cement and remnant intergranular porosity occluded by a drusy mosaic of nonferroan calcite cement (DC1). (F) Same photograph under CL. Isopachous relic fibrous cement (FC) shows "patchy" dull orange luminescence and drusy calcite (DC1) is NL. 

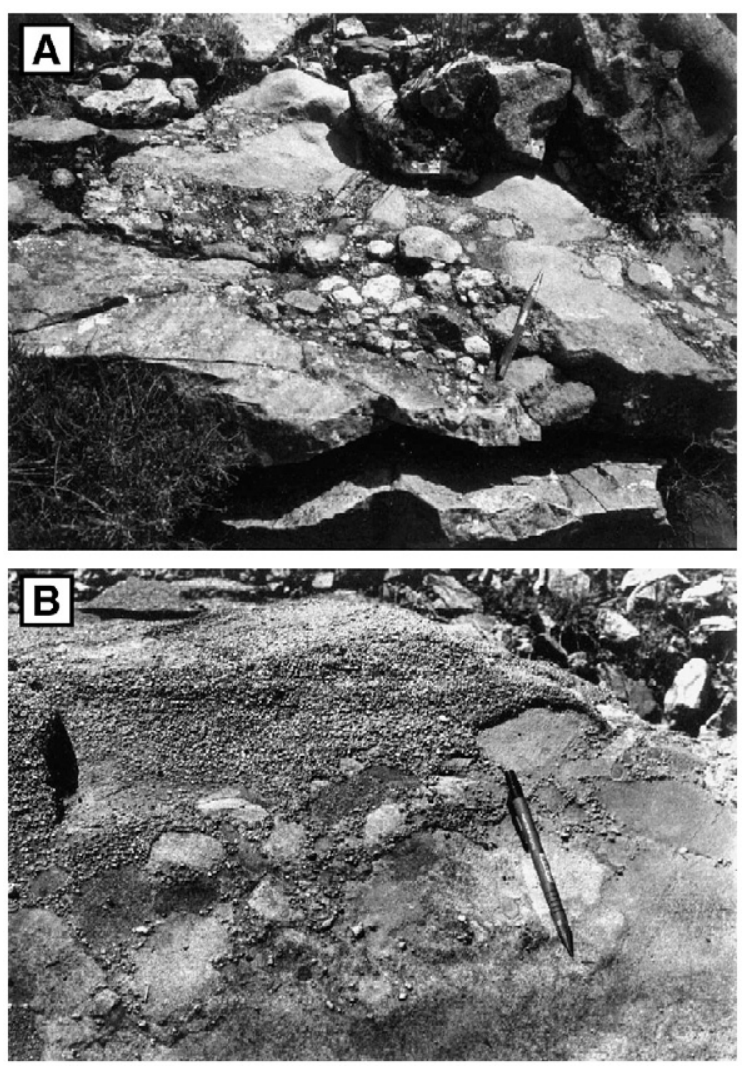

Fig. 6. (A) Storm beach conglomerate with oversized discoidal clasts at the top. (B) Storm beach deposit overlain by granule gravel with waveripple structures. Note granule gravel infiltrated into interstices between the storm beach clasts.

and sand (Bluck, 1967). Deposits of the 'outer frame zone' facies are represented by decimeter-thick beds where cobbles and pebbles occur dispersed within finer grained sediment.

Early diagenesis of both, fine- and coarse-grained beachface deposits is characterized by the precipitation of a drusy mosaic of NL nonferroan calcite cement in primary and moldic porosity or, less commonly, of zoned nonferroan to slightly ferroan NL-BL-DL calcite cement (Fig. 5C, D). As in the shoreface deposits, micrite envelopes mark the original shape of dissolved skeletal components. In some of the coarser grained deposits, a thin ferruginous rim, up to $10 \mu \mathrm{m}$ thick, developed around the grains prior to precipitation of the drusy calcite (Fig. 5C). These features suggest that early diagenesis of these deposits was controlled by meteoric processes.

\subsection{Beach ridges (FA 3)}

Shoreface deposits (FA 1) grade vertically into reddish stained, nodular and breccified sediments, devoid of primary sedimentary structures, which commonly contain abundant white-colored dinosaur eggs and eggshell fragments ('cascarenite' in Lopez-Martinez, 2000), as well as fully preserved clutches (Sanz et al., 1995; Sander et al., 1998). These facies are interpreted here as beach ridges sensu (Otvos, 2000; i.e., stabilized shore ridges including relict strandplain features, such as barriers, berms, chenier ridges and foredunes). Brecciation and reddish stain may also occur in the underlying shoreface sediments, but the wave ripple structures are still preserved.

Beach ridges are made up predominantly of fine- to medium-grained hybrid arenite, though some originated from storm beach conglomerates. In some cases (BT-2 in column1; Fig. 2), these were barrier ridges, as demonstrated by their lateral passage into washover fan and lagoonal deposits (Fig. 7B). Sandy beach ridge units either alternate with shoreface deposits (column 1, Fig. 2) or occur vertically stacked, reaching a total thickness of more than $10 \mathrm{~m}$ (between columns 4 and 5, Fig. 2). In the latter case, aggradation is documented by the presence of intercalated lagoonal sediments (column 5, Fig. 2).

The clutches of dinosaur eggs found in this facies (predominantly of the Megaloolithus oogenus) consist of two to seven closely spaced sub-spherical eggs (Fig. 8). Sometimes a serial paired order of the eggs is

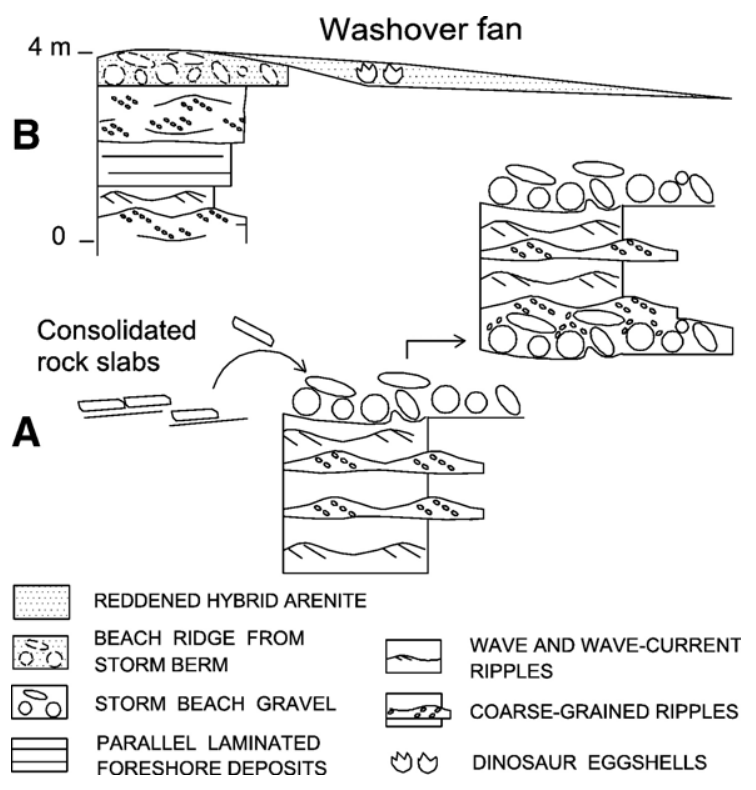

Fig. 7. (A) Typical sequences formed by shoreface deposits and storm beach conglomerates in unit BT-2. Open interstices between clasts of storm conglomerates were filled and the deposit finally covered by rippled granule gravel during subsequent flooding. (B) Synthetic column of top of subunit BT-2a (cf., Fig. 11), with lateral passage from beach ridge to washover deposits containing dinosaur eggs. 


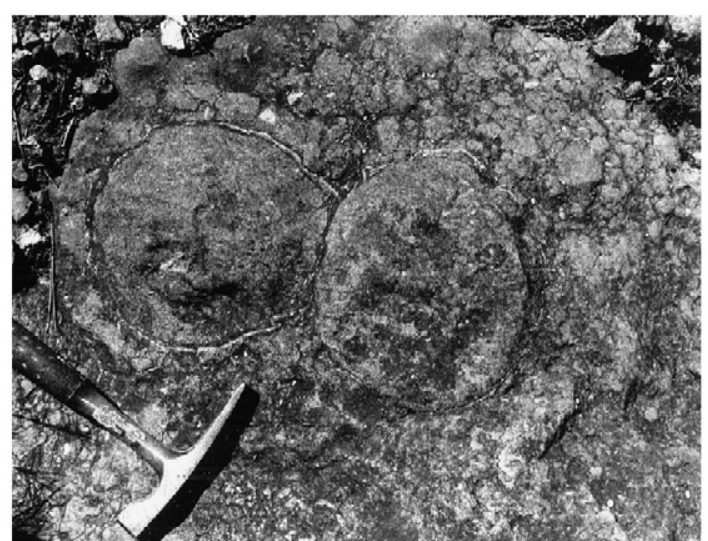

Fig. 8. Sections of two Megaloolithus-type dinosaur eggs. Original embedding sandy sediment was suitable for the respiration and humidity preservation of eggs, and thus compatible with a hole-nesting strategy, as common in recent turtles and crocodiles. The presence of dinosaur egg clutches in the sediment implies subaerial and vadose conditions. Later pedogenesis has affected differentially the eggshell-filling and surrounding sediment as shown by the different intensity of nodulization. observed (Sanz et al., 1995). Distance between separate clutches is in some cases less than $1 \mathrm{~m}$, similar to what has been observed by Chiappe et al. (2000) in Argentinian nesting sites. This short distance seems incompatible with simultaneous nesting of large dinosaurs. Apart from large eggs and eggshell fragments, 2$3 \mathrm{~mm}$ thick, of the oospecies Megaloolithus mamillare (Vianey-Liaud and Lopez-Martinez, 1997), smaller prismatoolitidae-type eggs and eggshell fragments, less than $0.5 \mathrm{~mm}$ thick, occur, which presumably belong to theropod dinosaurs. Sand and abundant shell debris fill all the eggs. A huge quantity of disperse eggshell fragments are visible in the exposure. The eggshell fragments have no preferred orientation and their fracture surfaces typically lack signs of abrasion. This suggests that they are the remains of previous clutches trampled by nesting dinosaurs and hatchlings.

The same as in shoreface deposits, very early diagenetic processes recorded in the beach ridge facies include partial micritization of carbonate grains and
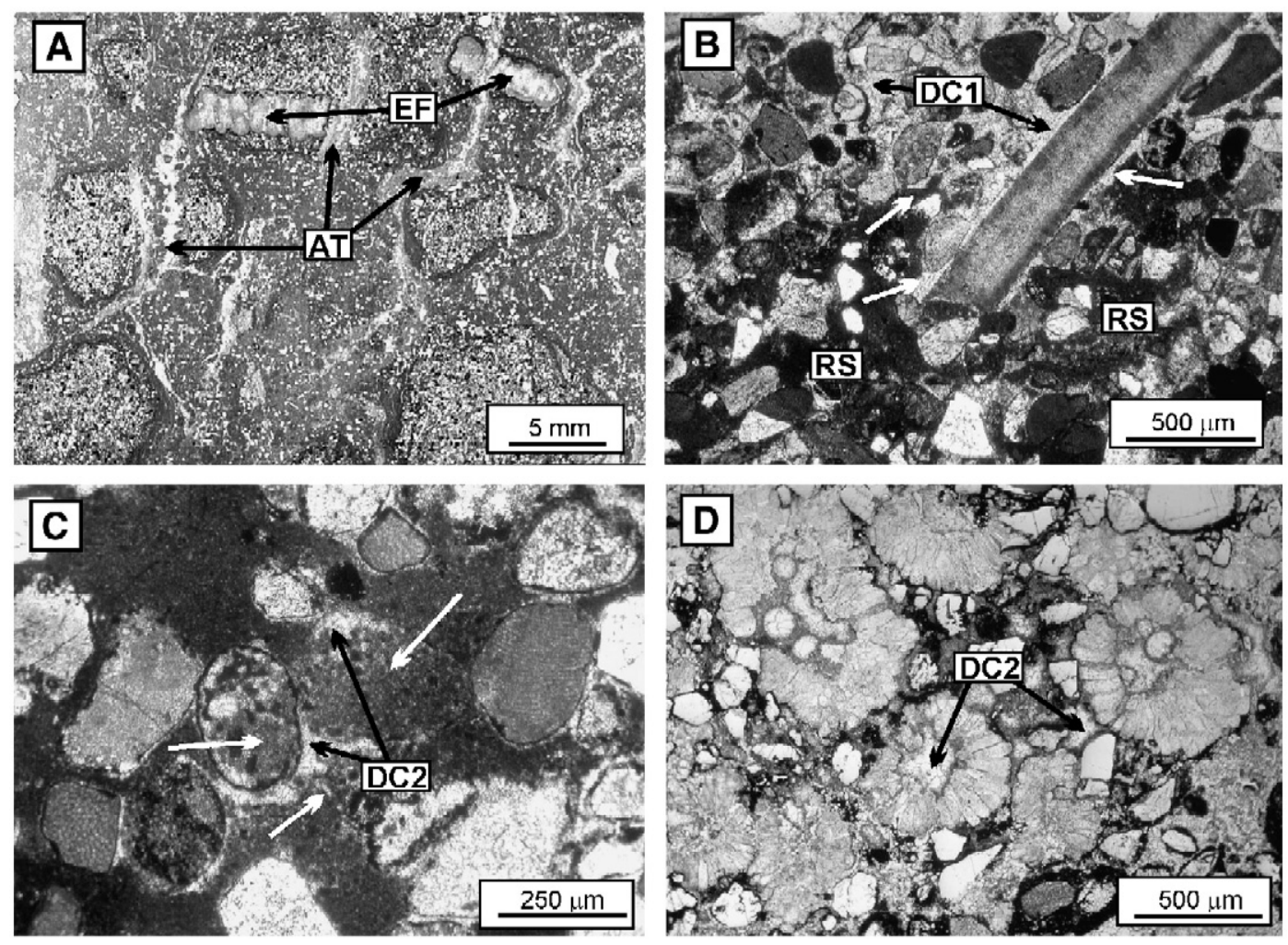

Fig. 9. (A) Reddish-colored hybrid arenite showing intense nodulization. Note the presence of eggshell fragments (EF), isolated or within nodules. Following nodulization the rock was fractured and the cracks filled by calcite that displays alveolar texture (AT). (B) Detailed view of hybrid arenite cemented by a drusy mosaic of nonferroan calcite cement (DC1). Both carbonate grains and cement were subsequently corroded and partially dissolved (white arrows). Undissolved grains ("residual sediment", RS) and abundant micrite matrix fills the newly created pore space. (C) Detailed view of two moldic cavities of dissolved carbonate grains filled by peloidal micrite, which also occurs in the intergranular porosity (arrows). Observe drusy calcite (DC2) postdating peloidal micrite. (D) Microcodium developed in the internodular "residual sediment", followed by precipitation of drusy calcite cement (DC2). 
precipitation of early isopachous fibrous marine calcite cement. Subsequently neomorphism and partial dissolution of skeletal grains and marine cements occurred, followed by precipitation of drusy calcite in the remaining primary and secondary porosity (Fig. 5E, F).

An important corrosion and dissolution of carbonate grains and previous cements led to the fragmentation, brecciation, nodulization and ferruginization of the incipiently lithified beach sand (Fig. 9A). The secondary porosity (vugs and fractures) thus created, as well as the earlier pores not occluded by cementation during the previous diagenetic stages, were filled by DL micrite matrix, often with peloidal fabric or, in case of larger cavities, by arenite matrix mainly composed of quartz, scattered skeletal grains and dinosaur eggshell fragments (Fig. 9B, C). Pore-filling sediment also contains abundant Microcodium and pisolithes (Fig. 9D), and may display alveolar texture with relics of needle-fibre calcite. All of these features are diagnostic of pedogenesis and the development of a soil profile under meteoric vadose conditions (e.g., Esteban and Klappa, 1983). The prevalent siliciclastic grain composition of the porefilling and internodular arenite matrix is due to selective leaching of carbonate grains and cements in the original deposit. Finally, nonferroan NL to zoned NL/BL mosaic of calcite cement, precipitated under meteoric phreatic conditions, occluded the remaining porosity.

\subsection{Backbarrier lagoon deposits (FA 4)}

Backbarrier sediments include facies representative of washover aprons and channels. Washover apron sediments are sandy conglomerates, with or without faint lamination, that grade laterally into sandy lime mudstones showing common color mottling, nodulization and burrowing, the same as is observed in recent examples from Florida (Sedwick and Davis, 2003). In places, calcimorphic and hydromorphic paleosols are developed. Sandy lime mudstones are poorly stratified, some of them are scour-based, with a lag of pebbles and cobbles. Washover fan deposits with scoured lower contacts and basal lags have been described from the Central Texas Coast (Andrews, 1970) and from the west-central Florida barrier island chain (Sedwick and Davis, 2003). In the Bastus exposure, the washover deposits overlie storm berm conglomerates (Fig. 7B) or lagoon deposits (units BT-2; Fig. 2). A sandy conglomerate at the top of subunit BT-2a contains a wellpreserved clutch of dinosaur eggs (Fig. 7B).

Poorly stratified or structureless sandy gravel characterizes the washover deposits of some recent gravel barrier beaches, as described by Orford and Carter (1982) and Carter et al. (1989). Similar facies have been interpreted as washover deposits in ancient barrier complexes (Noe-Nygaard and Surlyk, 1988; Le Roux and Elgueta, 1997). On the other hand, homogeneous or mottled sandy mud, comparable to the sandy lime mudstones mentioned above, is found in the muddy 'swampy areas' (Shepard and Moore, 1955) or 'stagnant outer fringe zone' of hurricane washover fans (e.g., on St. Joseph Island, Texas; Andrews, 1970), which are covered by a maze of permanent ponds and creeks surrounded by dense growth of typical marsh plants.

In the lower half of subunit BT-3b (column 4, Figs. 2 and 11), massive apron facies are incised by small channels, a few decimeters deep and generally less than a meter wide, infilled by clast-supported cobble and pebble conglomerates. These have the same composition as storm beach deposits and are supposed to have been sourced from them. These channelized conglomeratic
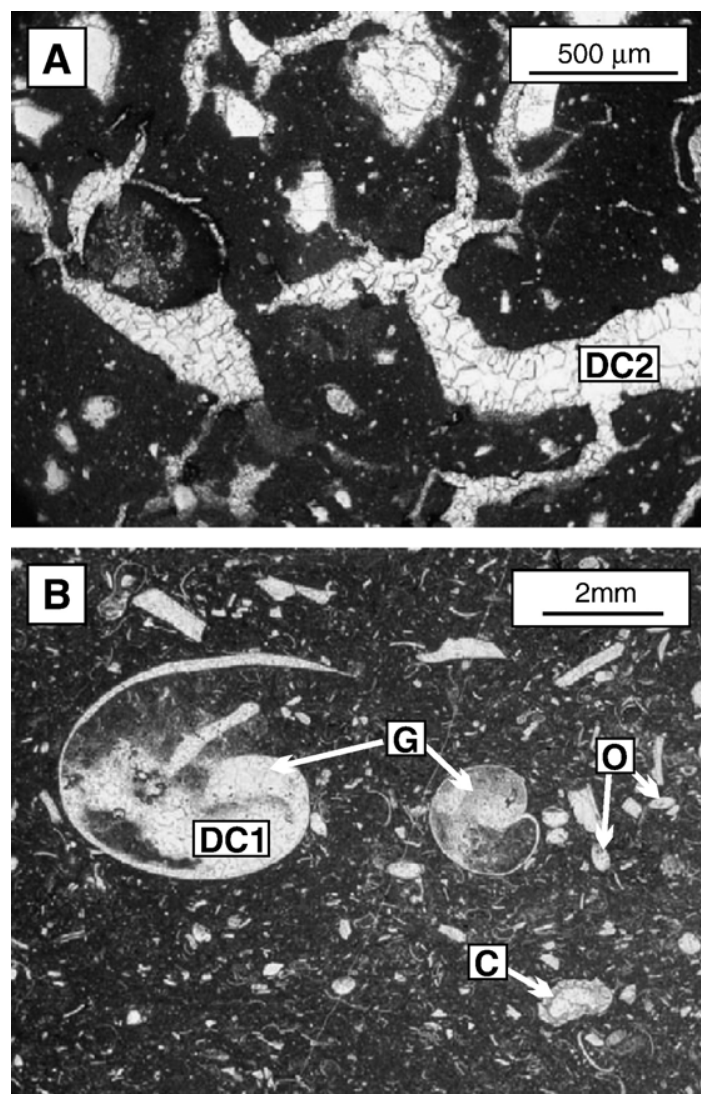

Fig. 10. Photomicrographs of backbarrier deposits. (A) Incipient nodulization in outer fringe deposit of washover fan; abundant circumgranular cracks, vugs and fractures are filled by a drusy mosaic of nonferroan calcite cement (DC2). (B) Lagoonal biomicrite rich in ostracod shells $(\mathrm{O})$, gastropods $(\mathrm{G})$ and subordinate charophytes $(\mathrm{C})$; both intraskeletal and moldic porosity after dissolution of gastropod shells is filled by a drusy mosaic of nonferroan calcite cement (DC1). 
deposits could in fact represent the infill (throat plugs) of storm swash-related breaches in the barrier crests (Orford and Carter, 1982), or of seepage hollows or channels behind the barriers (Carter and Orford, 1984).

Washover deposits contain abundant micrite matrix, thus visible primary porosity is very scarce or even absent. However, these deposits were affected by nodulization, circumgranular cracking and may display alveolar texture, generated during pedogenesis. Subsequently, a mosaic of NL nonferroan or DL slightly ferroan calcite cement precipitated in circumgranular cracks and vugs under meteoric phreatic conditions (Fig. 10A).

Lagoonal sediments include silty clay, common in analogous recent environments (e.g., Shepard and Moore, 1955; Dickinson et al., 1972; Oertel et al., 1989), as well as ostracod and gastropod-bearing biomicrites and marls. They probably formed in shallow waters, where sediment was supplied mainly by washover fans. Silty clays frequently show traces of plant roots and color mottling, due to changes in water saturation, and may contain angular blocky carbonate concretions, typical of hydromorphic paleosols. In places they are pervasively red stained, the same as adjacent beach ridge arenites (top of Unit BT-2 in column 5, Fig. 2). Biomicrites have a clotted texture and form continuous beds ranging between 0.20 and $1.40 \mathrm{~m}$ in thickness, and often becoming nodular upwards. These limestones probably mark episodes of reduced terrigenous influx into the lagoon. Scattered sand grains, probably wind-blown, are ubiquitous in the micrites.

In these lagoonal sediments, primary porosity is restricted to intraskeletal voids in ostracods, gastropods and charophytes (Fig. 10B). Pores are filled by a mosaic of slightly ferroan DL calcite cement followed by slightly ferroan dark DL calcite. This latter cement also filled moldic porosity generated after dissolution of gastropod shells.

Some backbarrier sediments are similar in composition to those of the beach ridges (FA 3), but differ from them by lacking prominent paleosol-related diagenetic features (BT-2b, column 5, Figs. 2 and 11), and are thus interpreted as flooded shore ridge sediments. They are fine- to medium-grained hybrid arenites with color mottling and strong bioturbation, and contain darkcolored dinosaur eggshell fragments and some dinosaur egg clutches. The pervasive burrowing and color mottling are indicative of a rise of the water table after dinosaur nesting. This different early diagenetic environment was probably responsible for the dark color of the eggshells (inhibited decay of organic matter) preserved in these sediments.

\section{Depositional architecture}

Several attempts have been made at analysing the Upper Cretaceous deposits of the south-central Pyrenean foreland basin in terms of sequence stratigraphy. Among others, Déramond et al. (1993) and Ardèvol et al. (2000) proposed subdivisions of the Aren Fm in sequence stratigraphic units and suggested correlations with contemporaneous tectonic activity, marked by incipient convergence and reactivation in inversion of Early Cretaceous extensional fault systems.

Fig. 11 includes a tentative correlation of the stratigraphic architecture of our units BT-1 to BT-3 with the

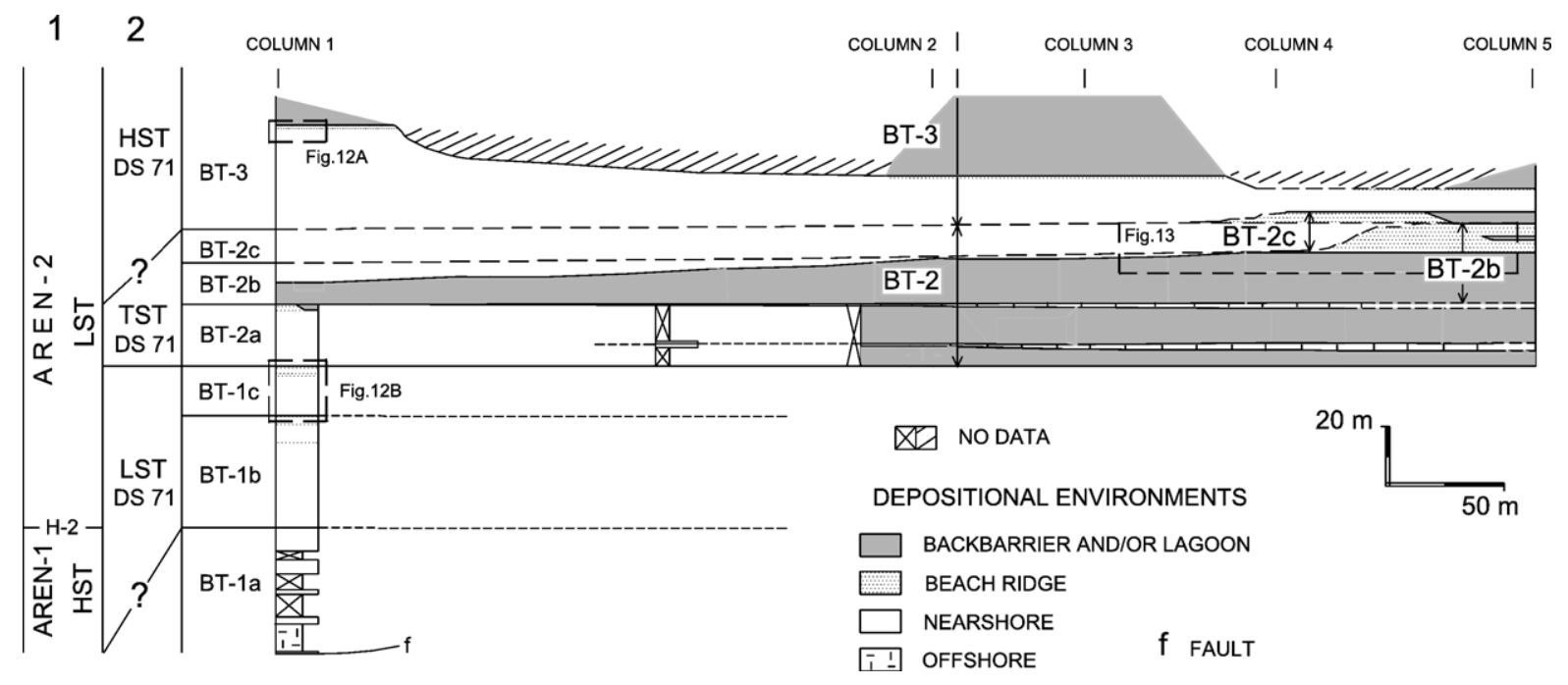

Fig. 11. Stratigraphic architecture of our units BT-1 to BT-3 compared to previous sequence stratigraphic interpretations based on regional-scale studies: (1) Ardèvol et al., 2000, (2) Déramond et al. (1993). 


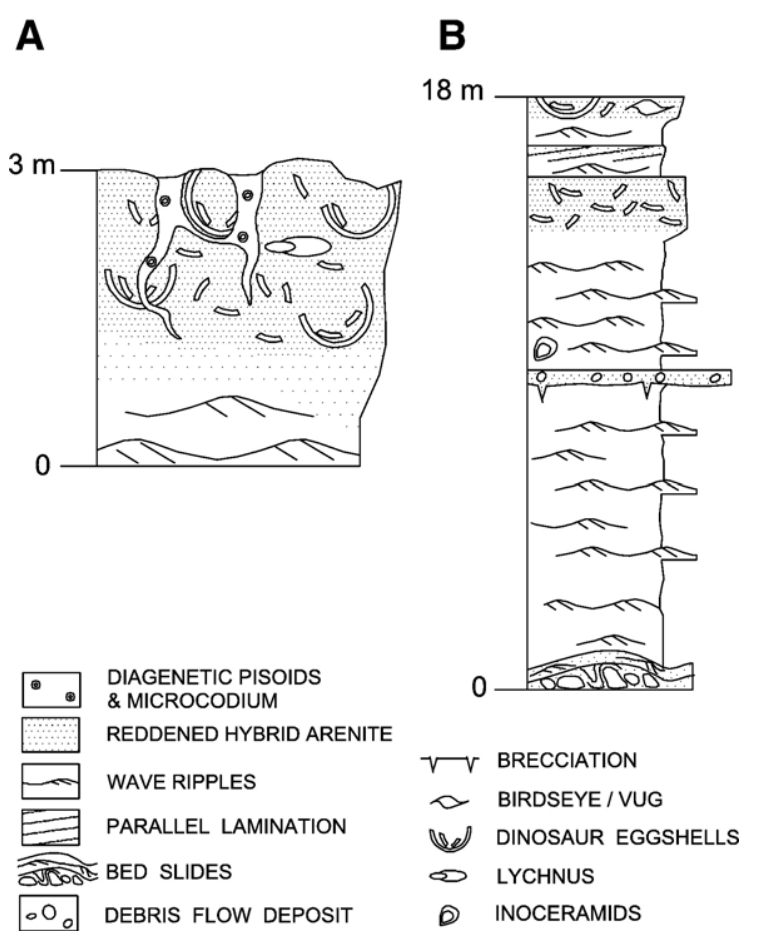

Fig. 12. (A) Summary of macroscopic features observed in dinosaur egg-bearing beach ridge sediments (see also Fig. 1b in Sanz et al., 1995). Pedogenic alteration and soil development started affecting the original shore ridge sandbodies after isolation from the active beach zone due to shoreline progradation, and essentially after dinosaur nesting. Pedogenic processes, the effects of which tend to decrease with depth, include ferruginization (red stain), corrosion, partial leaching of carbonate components, nodulization and brecciation that also affected the eggshell remains; crack/fracture filling, as well as internodular sediment contains abundant Microcodium and pedogenic pisoids (cf., Fig. 9). (B) Synthetic stratigraphic log of unit BT-1c (column 1, Fig. 11).

sequence stratigraphic interpretations proposed by Déramond et al. (1993) and Ardèvol et al. (2000). The portion of the Aren-2 sequence exposed at Bastus is considered by Ardèvol et al. (2000) to represent essentially lowstand deposits. However, in our view units BT-2 and BT-3 record a more complex sequential organization, similar to that proposed by Déramond et al. (1993), although a close comparison is impossible because of the more regional scale of their study, and thus the lack of detailed stratigraphic data.

\subsection{Unit BT-1}

Unit BT-1 comprises three parasequence sets (subunits BT-1a, -1b and -1c) with an upwards thinning trend. In subunit BT-1a parasequences are formed by offshore marls and nearshore arenites. Subunits BT-1b and $-1 \mathrm{c}$ are made up of shoreface deposits overlain by reddish beach ridge arenites, containing in cases dinosaur eggshells (Fig. 12B). Wave-rippled hybrid arenites at the base of parasequences commonly contain reddish clasts eroded from the substratum. In places, the base of a parasequence is marked by thin debris flow deposits containing pebble-sized arenite clasts, or by subaqueous slide deposits including up to boulder-sized clasts.

The lithological characteristics of BT-1 appear to be markedly uniform over about $25 \mathrm{~km}$ along the southern flank of the present E-W oriented Sant CorneliBóixols structure (Fig. 1), suggesting that the shoreline was oriented roughly parallel to its strike. By contrast, unit BT-2 shows a lateral transition from shoreface to lagoonal facies over a few hundred meters between the measured columns 1 and 2 (Figs. 2 and 11), indicating a change in shoreline orientation towards $\mathrm{N}-\mathrm{S}$.

\subsection{Unit BT-2}

Unit BT-2 has been subdivided into three subunits (BT-2a, -2b and -2c; Fig. 11). Subunit BT-2a in turn consists of three parasequences composed essentially of shoreface and foreshore deposits (column 1 in Figs. 2 and 11) that pass laterally into lagoonal deposits (column 4 in Fig. 2) The lateral passage from shoreface, beach face and beach ridge arenites into lagoonal limestones and washover deposits to the east implies the presence of barriers, a feature considered characteristic of transgressive coasts (e.g., Hoyd, 1967; Swift et al., 1991). Therefore, subunit BT-2a could represent part of the transgressive systems tract, as suggested by Déramond et al. (1993; TST of 'DS 71').

BT-2b and -2c represent two higher order (fourthorder, sensu Mitchum and Van Wagoner, 1991) retrogradational to aggradational sequences (cf., Fig. 11). Their genetic history is complex in detail and our interpretation in terms of sedimentary environments, inferred sea-level changes and resulting stacking patterns, is illustrated in Fig. 13.

Subunit BT-2b comprises washover fan, lagoonal and beach ridge facies (FA 3 and 4, Fig. 2), which are truncated by a stepped surface of transgressive erosion (Figs. 2 and 4), or ravinement surface sensu Stamp (1921, in Bertram et al., 1996). A lag deposit occurs associated with this surface. It consists either of scattered cobbles and pebbles, or sandy conglomeratic beds, up to $20 \mathrm{~cm}$ thick. This lag does not actually represent a single and laterally continuous bed, but instead originated by erosion and deposition associated with successive retrogradational parasequences made up of shoreface and storm beach deposits (Fig. 2; stage 1, Fig. 13). The lagoonal, backbarrier and beach ridge 

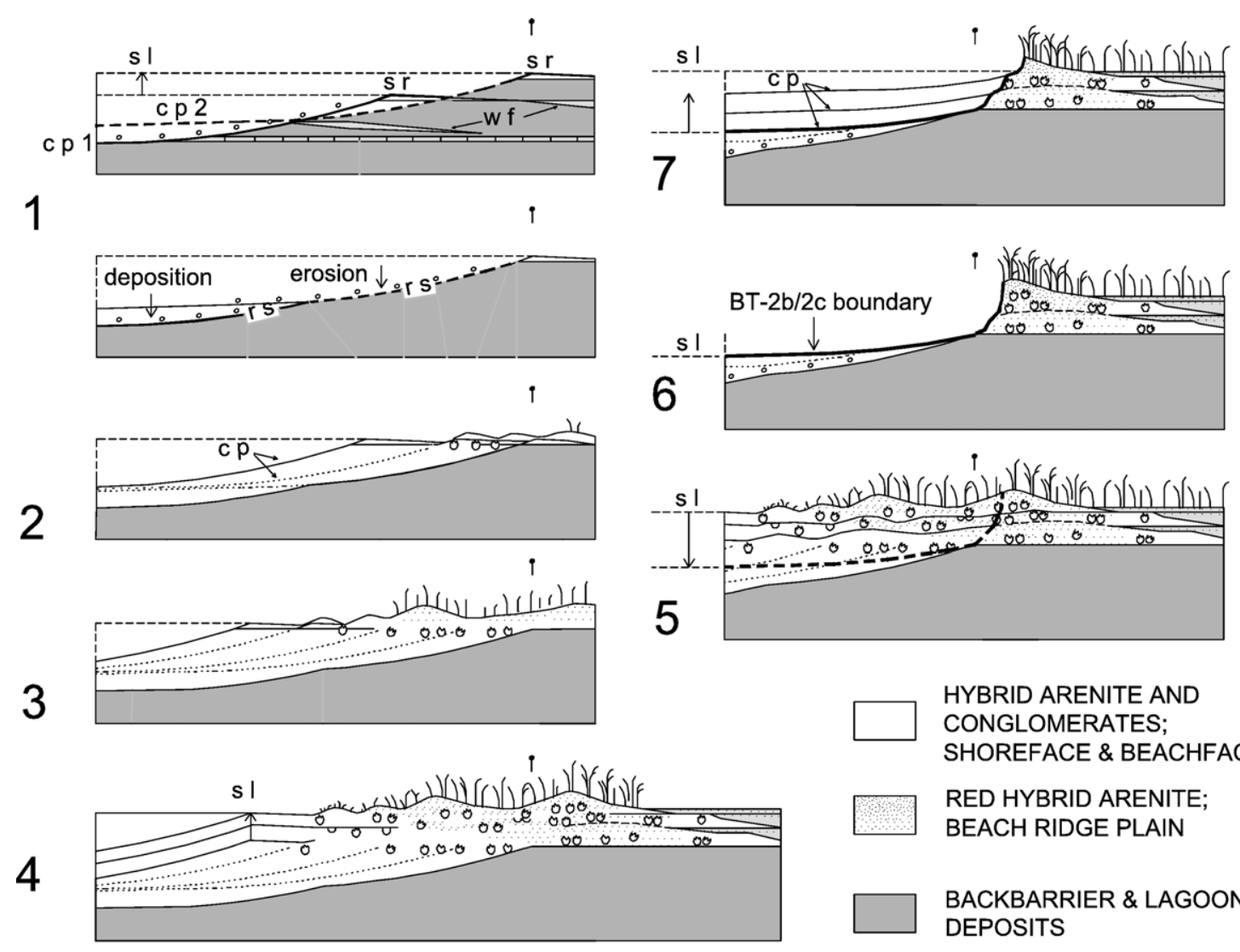

HYBRID ARENITE AND CONGLOMERATES; SHOREFACE \& BEACHFACE

RED HYBRID ARENITE; BEACH RIDGE PLAIN

\section{BACKBARRIER \& LAGOONAL} DEPOSITS

\section{Ð DINOSAUR EGGS}

$w f$ WASHOVER FAN

\section{LIMESTONE $\quad$ F FIXED PIN POINT}

Fig. 13. Reconstructed sedimentary history of the upper part of unit BT-2b (cf., Fig. 11). (1) As a consequence of sea-level (sl) rise, the coastal equilibrium profile (cp1) shifts landwards (cp2) and upper shoreface, shore ridge (sr) and lagoonal deposits of the previous profile are eroded (rs = ravinement surface); erosion and deposition zones after Bruun (1962). (2-3) Progradation, dinosaur nesting behind active beach zone and beach ridge formation. (4) Aggradation. (5-6) Sea-level fall with consequent erosion/cliff formation. (7) Sea-level rise and related reworking of the cliff.

facies preserved beneath the ravinement surface presumably formed part of the same cycle (Bertram et al., 1996) and were variably affected by erosion during subsequent landwards migration of coastal equilibrium profiles (Fig. 13).

The stacking pattern of beach ridge arenites between columns 4 and 5 is aggradational (stage 4, Fig. 13). These deposits are interpreted as the remains of ridge plain features fringing the lagoonal deposits present to the east of the studied exposure. The erosional surfaces, cutting the beach ridge arenites in both sequences BT-2b and BT-2c (Fig. 14), record relative sea-level falls and subsequent rises (stages 5 to 7, Fig. 13). Where affecting early-cemented beach ridge facies, erosional surfaces slope more steeply. The preserved overall thickness of the stacked beach ridge relicts in BT-2b indicates that the sea-level fall preceding BT-2c must have exceeded
$10 \mathrm{~m}$ (Fig. 15). The boundary between both sequences can be only locally recognized in outcrop (between columns 4 and 5, Fig. 2), because of the similarity between the lithologies beneath and above.

\section{3. $B T-3$}

This unit is progradational and is formed by shallowmarine (Aren Fm) and its correlative lagoonal and alluvial deposits (Tremp Fm). Three parasequences can be distinguished between columns 2 and 5 (Fig. 15), each of them consisting of shoreface arenites at the base grading upwards into beach ridge arenites. Clutches of dinosaur eggs and eggshell fragments are common in the beach ridge facies, and clutches exceptionally occur also within underlying shoreface deposits (e.g., parasequence BT-3a; column 5, Fig. 15). 

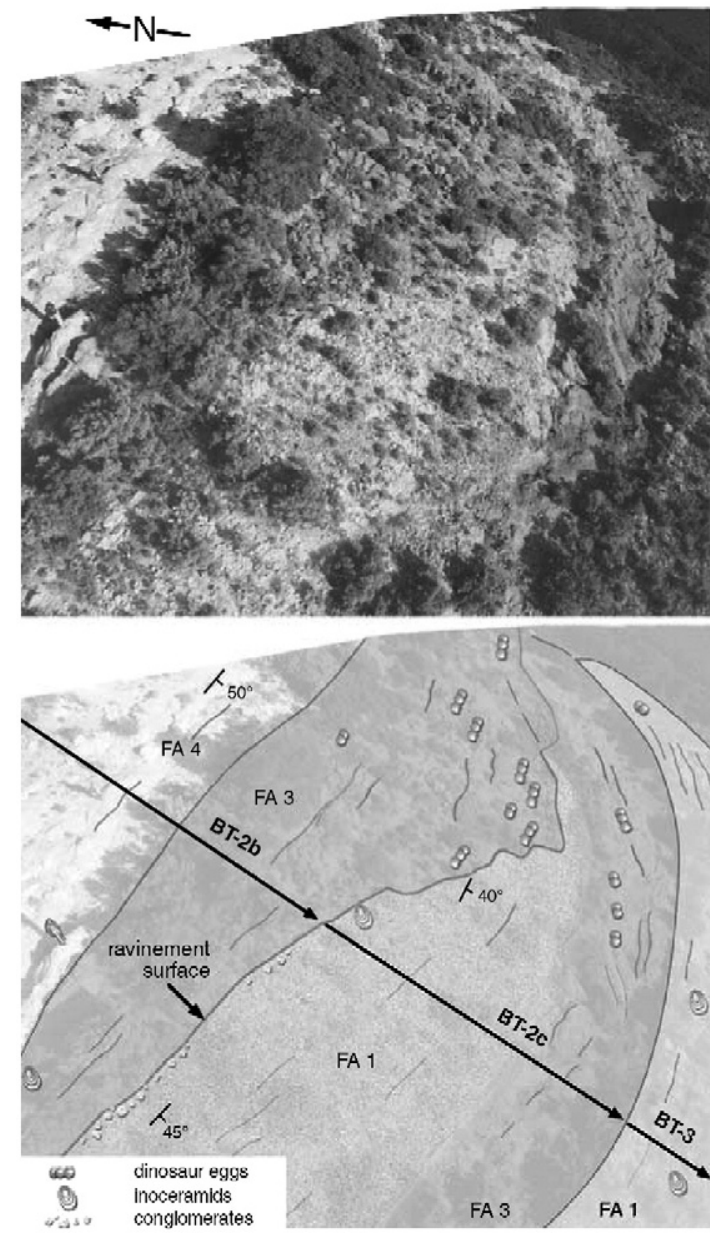

Fig. 14. Aerial photograph, oblique view (from NW), of the transgressive ravinement surface between subunits BT-2b and BT-2c (cf., Fig 11) with explanatory line drawing below. FA 1, 3 and 4 refer to facies assemblages described in the text. Person at the centre left of photograph for scale.
The lowermost parasequence, BT-3a, is bounded below by an erosional surface, interpreted to be the result of a fall and subsequent rise of sea level with an estimated amplitude of $4 \mathrm{~m}$ at least (Fig. 15). A mound-like topography formed by beach ridge arenites, presumably representing an erosional relict of the beach ridge plain, is also preserved at the top of BT-3b between columns 2 and 3 (Fig. 15). In the western portion of the exposure studied (column 1, Fig. 2), the distinction of individual parasequences is impeded by the monotonous lithologic character, however, a package of eggshell-bearing red arenites (Sanz et al., 1995) again occurs at the top of shoreface deposits, marking the contact with the overlying lagoonal sediments of the Tremp Fm.

\section{Conclusions}

The upper Campanian record exposed near Bastus includes deposits of offshore, shoreface, beachface, beach ridge plain, backbarrier and lagoonal environments. Dinosaur eggshell remains predominantly occur in reddish arenites interpreted as relics of beach ridge plain sediments. The notable number of preserved clutches and the high concentration of eggshell debris in this facies indicate site fidelity of the nesting dinosaurs.

Beach ridge sediments, represented by breccified and nodulized red arenites, are the product of a complex depositional and early diagenetic history. They originated from shore ridges including sandy or gravelly berms and barriers. After isolation of the shore ridges from the active beach zone, due to shoreline progradation, unconsolidated sands of the strand plain provided a favourable ground for dinosaur nesting. Subsequent pedogenesis resulted in stabilization of former shore ridges ('beach ridges' of Otvos, 2000). Occasionally dinosaur eggs are found within sandy washover deposits.

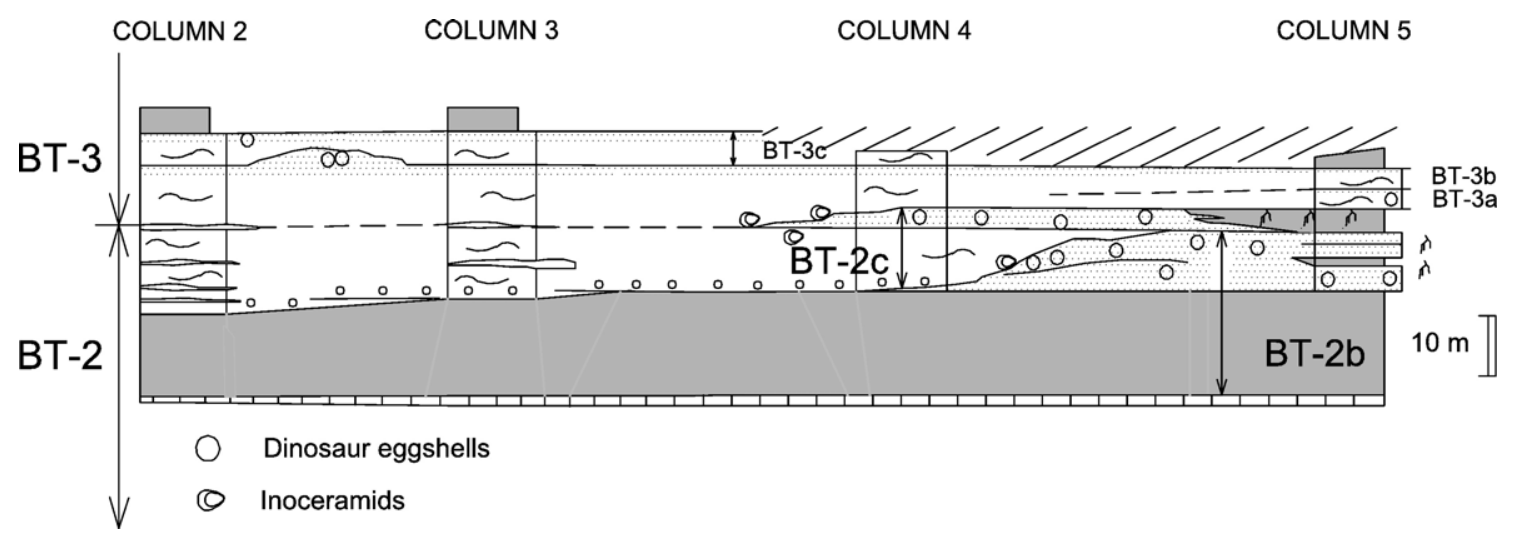

Fig. 15. Subunits BT-2b, BT-2c and lower portion of BT-3 showing the distribution of beach ridge sediments containing dinosaur eggshells. See legend in Fig. 2. 
Particularly thick packages of dinosaur eggshellbearing red arenite (in subunits BT-2b and $-2 c$ ) resulted from aggradation of barrier/ridge plain deposits, and their preservation below surfaces of transgressive erosion was favoured by incipient lithification. The erosional surfaces, cutting the beach ridge arenites record relative sea-level falls and subsequent rises of higher order cyclicity.

The observed depositional architecture, which records a transgressive episode (unit BT-2), better agrees with the sequence stratigraphic interpretation of Déramond et al. (1993), than that of Ardèvol et al. (2000). The reddish beach ridge facies appear at the top of parasequences forming a low stand (BT-1), a transgressive (BT-2) and a high stand (BT-3) system tract of a third-order sequence (Aren-2 of Ardèvol et al., 2000 or 'DS 71' of Déramond et al., 1993). Subunit BT1a could form part of the underlying sequence (Aren-1 of Ardèvol et al., 2000 or 'DS 75' of Déramond et al., 1993).

\section{Acknowledgements}

We wish to thank P. Friend for the comments on an earlier draft of this paper. We also thank L. Ardèvol for his help during field work and for the stimulating discussions, and J. Van Itterbeeck and an anonymous reviewer for their critical comments on the original manuscript. Financial support was provided by "Ministerio de Educación y Ciencia" (Spain, BTE2002-1430 project).

\section{References}

Arbués, P.E.P., Berástegui, X., 1996. Relaciones entre la evolución sedimentaria del Grupo de Aren y el Cabalgamiento de Boixols (Campaniense terminal-Maastrichtiense del Pirineo MeridionalCentral). Geogaceta 20, 446-449.

Ardèvol, L., Klimowitz, J., Malagón, J., Nagtegaal, P.J.C., 2000. Depositional sequence response to foreland deformation in the Upper Cretaceous of the Southern Pyrenees, Spain. American Association of Petroleum Geology, Bulletin 84, 566 -587.

Andrews, P.B., 1970. Facies and genesis of a hurricane-washover fan, St. Joseph Island, Central Texas Coast. Report of Investigation, vol. 67. Univ. Texas, Austin, Bureau of Economic Geology. 147 pp.

Bertram, G., Griffiths, C., Milton, N., Reynolds, T., Richards, M., Sturrock, S., 1996. In: Emery, D., Myers, K. (Eds.), Sequence Stratigraphy. Blackwell Science, Oxford. 297 pp.

Bluck, B.J., 1967. Sedimentation of beach gravels: examples from South Wales. Journal of Sedimentary Petrology 37, 128-156.

Bond, R.M.G., McClay, K.R., 1995. Inversion of a Lower Cretaceous extensional basin, south-central Pyrenees, Spain. In: Buchanan, J.G., Buchanan, P.G. (Eds.), Basin inversion. Geological Society of London, Special Publication, vol. 88, pp. 415-431.

Bruun, P., 1962. Sea level rise a cause of shore erosion. American Society of Civil Engineers. Journal of Waterways and Harbour Division 71, $1729-1754$.
Carter, R.W.G., Orford, J.D., 1984. Coarse clastic barrier beaches: a discussion of the distinctive dynamic and morphosedimentary characteristics. Marine Geology 60, 377-389.

Carter, R.W.G., Forbes, D.L., Jennings, S.C., Orford, J.D., Shaw, J., Taylor, R.B., 1989. Barrier and lagoon coast evolution under differing relative sea-level regimes: examples from Ireland and Nova Scotia. Marine Geology 88, 221-242.

Chiappe, L., Dingus, L., Jackson, F., Grellet-Tinner, G., Aspinall, R., Clarke, J., Coria, R., Garrido, A., Loope, D., 2000. Sauropod eggs and embryos from the Late Cretaceous of Patagonia. In: Bravo, A., Reyes, T. (Eds.), First International Symposium on Dinosaur Eggs and Babies. Extended Abstracts. Publicaciones de la Excelentísima Diputación de Lleida, pp. 23-29.

Clifton, H.E., 1973. Pebble segregation and bed lenticularity in wave worked versus alluvial gravel. Sedimentology 20, 173-187.

Clifton, H.E., Hunter, R.E., Phillips, R.L., 1971. Depositional structures and processes in the non-barred high-energy nearshore. Journal of Sedimentary Petrology 41, 651-670.

Cojan, I., Renard, M., Emmanuel, L., 2003. Paleoenvironmental reconstruction of dinosaur nesting sites based on a geochemical approach to eggshells and associated paleosols (Maastrichtian Provence Basin, France). Palaeogeography, Palaeoclimatology, Palaeoecology 191, 111-138.

Déramond, J., Souquet, P., Fondecave-Wallez, M.-J., Specht, M., 1993. Relationships between thrust tectonics and sequence stratigraphy surfaces in foredeeps: model and examples from the Pyrenees (Cretaceous-Eocene, France, Spain). In: Williams, G.D., Dobb, A. (Eds.), Tectonics and Seismic Sequence Stratigraphy. Geological Society of London, Special Publication, vol. 71, pp. 193-219.

Díaz-Molina, M., 1987. Sedimentación sintectónica asociada a una subida relativa del nivel del mar durante el Cretácico Superior (Fm. Tremp, provincia de Lérida). Estudios geológicos, vol. extraordinario Galve-Tremp, pp. 69-93.

Dickinson, K.A., Berryhill Jr., H.L., Holmes, C.W., 1972. Criteria for recognizing ancient barrier coastlines. In: Rugby, J. Keith (Ed.), Recognition of Ancient Sedimentary Environments. Society of Economic Paleontologists and Mineralogists, Special Publication, 16, pp. 192-214.

Dickson, J.A.D., 1966. Carbonate identification and genesis as revealed by staining. Journal of Sedimentary Petrology 36, 491-505.

Dingus, L., Clarke, J., Scott, G.R., Swisher, C., Chiappe, L.M., Coria, R., 2000. Stratigraphy and magnetostratigraphic/faunal constraints for the age of sauropod embryo-bearing rocks in the Neuquén Group (Late Cretaceous, Neuquén Province, Argentina). American Museum Novitates 3290, 1-11.

Escuer, J., Peralba, J., Cusso, R., Jiménez, A., Borrull, J., Perez, P., Umbert, M., Garrabou, E., Bons, N., Garrabou, M., Regal, C., 2003. Sallent Valley, recurrent dinosaur nesting site from the Late Cretaceous of southern Pyrenees (Coll de Nargo, Spain): a GIS approach. 2nd International Symposium on Dinosaur Eggs and Babies, Montpellier. Abstract, vol. 11.

Esteban, M., Klappa, C.F., 1983. Subaerial exposure environment. In: Scholle, P.A., Bebout, D.G., Moore, C.H. (Eds.), Carbonate Depositional Environments. American Association of Petroleum Geologists, Memoir, vol. 33, pp. 1-92.

Eichenseer, H. 1988. Facies geology of late Maastrichtian to early Eocene coastal to shallow-marine sediments, Tremp-Graus Basin, northeastern Spain: PhD thesis. University of Tübingen, Tübingen, Germany, 237 pp.

Garrido Mejias, A. 1973. Estudio geológico y relación entre tectónica y sedimentación del Secundario y Terciario de la vertiente meridional 
pirenaica en su zona central (provincia de Huesca y Lérida). PhD thesis: Universidad de Granada, Spain, 395 pp.

Gradstein, F., Ogg, J., Smith, A., 2004. A Geologic Time Scale. Cambridge University Press, Cambridge. 589 pp.

Hardenbol, J., Thierry, J., Farley, M.B., Jacquin, Th., Vail, P.R., 1998. Cretaceous sequence chronostratigraphy. In: De Graciansky, P.C., Hardenbol, J., Jacquin, Th., Vail, P.R. (Eds.), Mesozoic and Cenozoic Sequence Stratigraphy of European Basins. Society of Economic Paleontologists and Mineralogists, Special Publication, vol. 60. Chart no. 4.

Hart, B.S., Plint, A.G., 1989. Gravelly shoreface deposits a comparison of modern and ancient facies sequences. Sedimentology 36, 551-557.

Hoyd, J.H., 1967. Barrier island formation. Geologial Society of American, Bulletin 78, 1123-1136.

James, N.P., Choquette, P.W., 1990. Limestones-the meteoric diagenetic environment. In: McIlreath, I.A., Morrow, D.W. (Eds.), Diagenesis Geoscience Canada. Reprint Series, vol. 4, pp. $35-73$.

Le Roux, J.P., Elgueta, S., 1997. Paralic parasequences associated with Eocene sea-level oscillations in an active margin setting: Trihueco Formation of the Arauco Basin, Chile. Marine Geology 10, 257-276.

Leckie, D., 1988. Wave formed, coarse-grained ripples and their relationship to hummocky cross stratification. Journal of Sedimentary Petrology 58, 607-622.

Lopez-Martinez, N., 2000. Eggshell sites from the CretaceousTertiary transition in south-central Pyrenees (Spain). In: Bravo, A., Reyes, T. (Eds.), First International Symposium on Dinosaur Eggs and Babies. Extended Abstracts. Publicaciones de la Exma. Diputación de Lleida, pp. 95-115.

Lopez-Martinez, N., Moratalla, J.J., Sanz, J.L., 2000. Dinosaur nesting on tidal flats. Palaeogeography, Palaeoclimatology, Palaeoecology $160,153-163$.

Lopez-Martinez, N., Canudo, J.I., Ardèvol, L., Pereda Suberbiola, X., Orue-Etxebarría, X., Cuenca-Bescós, G., Ruiz Omeñaca, J.I., Murelaga, X., Feist, M., 2001. New dinosaur sites correlated with Upper Maastrichtian pelagic deposits in the Spanish Pyrenees: implications for the dinosaur extinction pattern in Europe. Cretaceous Research 22, 41-61.

Losantos, M., Aragonés, E., Berástegui, X., Palau, J., Puigdefábregas, C., 2002. Mapa Geològic de Catalunya at scale 1: 250.000 (second ed.). Institut Cartogràfic de Catalunya. Barcelona.

McCubbin, D.G., 1982. Barrier-island and strand-plain facies. In: Scholle, P.A., Spearing, D. (Eds.), Sandstone Depositional Environments. American Association of Petroleum Geologists, Memoir, vol. 31, pp. 247-279.

Mey, P.H.W., Nagtegaal, P.J.C., Roberti, K.J., Hartevelt, J.J.A., 1968. Lithostratigraphic subdivision of post-hercynian deposits in the south-central Pyrenees, Spain. Leidse Geologische Mededelingen 41, 221-228.

Meyers, W.J., 1991. Calcite cement stratigraphy: an overview. In: Barker, Ch.E., Kopp, O.C. (Eds.), Luminescence Microscopy and Spectroscopy: Qualitative and Qualitative Applications. Short Course, 25. Society of Economic Paleontologists and Mineralogists, pp. 133-148.

Mitchum Jr., R.M., Van Wagoner, J.C., 1991. High-frequency sequences and their stacking patterns: sequence-stratigraphic evidence of high-frequency eustatic cycles. Sedimentary Geology 70, 131-160.

Nagtegaal, P.J.C., Van Vliet, A., Brouwer, J., 1983. Syntectonic coastal offlap and concurrent turbidite deposition: the Upper Cretaceous Aren Sandstone in the south-central Pyrenees, Spain. Sedimentary Geology 34, 185-218.
Noe-Nygaard, N., Surlyk, F., 1988. Washover fan and brakish bay sedimentation in the Berriasian-Valangian of Bornholm, Denmark. Sedimentology 35, 197-217.

Oertel, G.F., Kearney, M.S., Leatherman, S.P., Woo, H., 1989 Anatomy of a barrier platform: outer barrier lagoon, southern Delmarva peninsula, Virginia. Marine Geology 88, 303-318.

Orford, J.D., Carter, R.W.G., 1982. Crestal overtop and washover sedimentation on a fringing sandy gravel barrier coast, Carnsore Point, Southeast Ireland. Journal of Sedimentary Petrology 52, $265-278$.

Otvos, E.G., 2000. Beach ridges-definitions and significance. Geomorphology 32, 83-108.

Paik, I.S., Huh, M., Kim, H.J., 2004. Dinosaur egg-bearing deposits (Upper Cretaceous) of Boseong, Korea: occurrence, palaeoenvironments, taphonomy, and preservation. Palaeogeography, Palaeoclimatology, Palaeoecology 205, 155-168.

Postma, G., Nemec, W., 1990. Regressive and transgressive sequences in a raised Holocene gravely beach, southwestern Crete. Sedimentology 37, 907-920.

Puigdefábregas, C., Souquet, P., 1986. Tecto-sedimentary cycles and depositional sequences of the Mesozoic and Tertiary from the Pyrenees. Tectonophysics 129, 173-203.

Sander, P.M., Peitz, C., Gallemi, J., Cousin, R., 1998. Dinosaur nesting on a red beach? Comptes Rendues de la Académie des Sciences de Paris. Sciences de la Terre et des Planets 327, 67-74.

Sanz, J.L., Moratalla, J.J., Díaz-Molina, M., Lopez-Martinez, N., Kälin, O., Vianey-Liaud, M., 1995. Dinosaur nests at the sea shore. Nature 376, 731-732.

Scholle, P.A., Ulmer-Scholle, D.S., 2003. A color guide to the petrography of carbonate rocks: grains, textures, porosity, diagenesis. American Association of Petroleum Geologists, Memoir vol. 77474 pp.

Sedwick, P.E., Davis Jr., R.A., 2003. Stratigraphy of washover deposits in Florida: implication for recognition in the stratigraphic record. Marine Geology 200, 31-48.

Sgavetti, M., 1994. Photostratigraphic characteristics of sequence stratigraphic features and patters: Upper Cretaceous and Eocene Strata of the south-central Pyrenees, Spain. In: Weimer, P., Posamentier, W. (Eds.), Siliciclastic Sequence StratigraphyRecent Developments and Applications. American Association of Petroleum Geologists, Memoir, vol. 58, pp. 411-447.

Simó, A., 1986. Carbonate platform depositional sequences, Upper Cretaceous, south-central Pyrenees (Spain). Tectonophysics 129, 205-231.

Simó, A., 1989. Upper Cretaceous platform-to-basin depositionalsequence development, Tremp Basin, south-central Pyrenees, Spain. In: Crevello, P.D., Wilson, J.L., Sarg, J.F., Read, J.F. (Eds.), Controls on Carbonate Platform and Basin Development. Society of Economic Paleontologists and Mineralogists, Special Publication, vol. 44, pp. 365-387.

Shepard, F.P., Moore, D.G., 1955. Central Texas coast sedimentation: characteristics of sedimentary environments, recent history, and diagenesis. American Association of Petroleum Geologists, Bulletin 39, 1463-1593.

Stamp, L.D., 1921. On cycles of sedimentation in the Eocene strata of the Anglo-France-Belgium Basin. Geological Magazine 58, $108-114$.

Swift, D.J.P., Phillips, S., Thorne, J.A., 1991. Sedimentation on continental margins: IV. Lithofacies and depositional systems. In: Swift, D.J.P., Oertel, G.F. (Eds.), Shelf Sand and Sandstone Bodies. International Association of Sedimentologists. Spec. Publ., vol. 14. Blackwell, Oxford, pp. 89-152. 
Tandon, S.K., Sood, A., Andrews, J.E., Dennis, P.F., 1995. Palaeoenvironments of the dinosaur-bearing Lameta Beds (Maastrichtian), Narmada Valley, Central India. Palaeogeography, Palaeoclimatology, Palaeoecology 117, 153-184.

Taylor, M., Stone, G.W., 1996. Beach-ridges: a review. Journal of Coastal Research 12, 612-621.

Tucker, M., Wright, V.P., 1990. Carbonate Sedimentology. Blackwell Scientific Publications, Oxford. 82 pp.

Van Wagoner, J.C., Posamentier, H.W., Mitchum, R.M., Vail, P.R., Sarg, J.F., Loutit, T.S., Hardenbol, J., 1988. An overview of the fundamentals of sequence stratigraphy and key definitions. In: Wilgus, C.K., Posamentier, H.W., Ross, C.A., Kendall, G. St. C.
(Eds.), Sea level Changes: An Integrated Approach. Society of Economic Paleontologists and Mineralogists, Special Publication, vol. 42, pp. 39-45.

Van Itterbeeck, J., Sasaran, E., Codrea, V., Sasaran, L., Bultynck, P., 2004. Sedimentology of the Upper Ctretaceous mammal- and dinosaur-bearing sites along the Râul Mare and Barbat rivers, Hateg Basin, Romania. Cretaceous Research 25, 517-530.

Vianey-Liaud, M., Lopez-Martinez, N., 1997. Late Cretaceous dinosaur eggshells (Saurischia) from the Tremp Basin (Southern Pyrenees, Lleida, Spain). Journal of Paleontology 71, 1157-1171.

Williams, A.T., Caldwell, N.E., 1988. Particle size and shape in pebble-beach sedimentation. Marine Geology 82, 199-215. 